\title{
Rapid, Affordable, Collection and Analysis of Bioaerosol Viral Pathogen
}

21 Laboratory, Ft. Pierce, Florida, 34945, USA. Wayne.hunter@ars.usda.gov

$23{ }^{2}$ Consulting Engineer, Electrostatic Space Charge Systems, LLC. USA, Tel: 706.202.9161

24 baileywmitchell@,charter.net

$25 *$ Contact: Dr. Bailey Mitchell, Email: baileywmitchell@charter.net 
31 Detection of pathogens is critical to monitoring their distribution and spread, and is a key

32 component in the prediction and management of disease epidemiology. Monitoring for

33 pathogens as bioaerosols requires developing techniques which are sensitive, affordable, and

34 time saving before they will have widespread impact. This approach also overcomes private

35 property issues, which are a major pitfall in monitoring diseases in complex agricultural and

36 urban settings. In this study, we have applied an emerging technology of electrostatic sampling

37 to the detection of an insect-transmitted plant pathogen as a bioaerosol. Where insects aggregate

38 in large numbers, as with whiteflies, leafhoppers, psyllids and honey bees, the pathogen (ie. virus

39 or bacteria) becoming aerosolized as thousands of excreta droplets fall from the plants during

40 feeding. Agricultural systems have not fully measured the impact of bioaerosols on disease

41 epidemiology. Electrostatic sampling provides a valuable, affordable, method for monitoring for

42 diseases as bioaerosols, which includes plant, animal and human pathogens. This study shows

43 results which successfully used an electrostatic sampling device to collect an aerosolized

44 begomovirus from the air near whiteflies feeding on virus-infected tomato plants.

45 Keywords: Air, Begomovirus, Bemisia, Bioaerosol, Collect, Electrostatic, TYLCV, Virus 
bioRxiv preprint doi: https://doi.org/10.1101/451559; this version posted October 24,2018 . The copyright holder for this preprint (which was not certified by peer review) is the author/funder. This article is a US Government work. It is not subject to copyright under 17 USC 105 and is also made available for use under a CCO license.

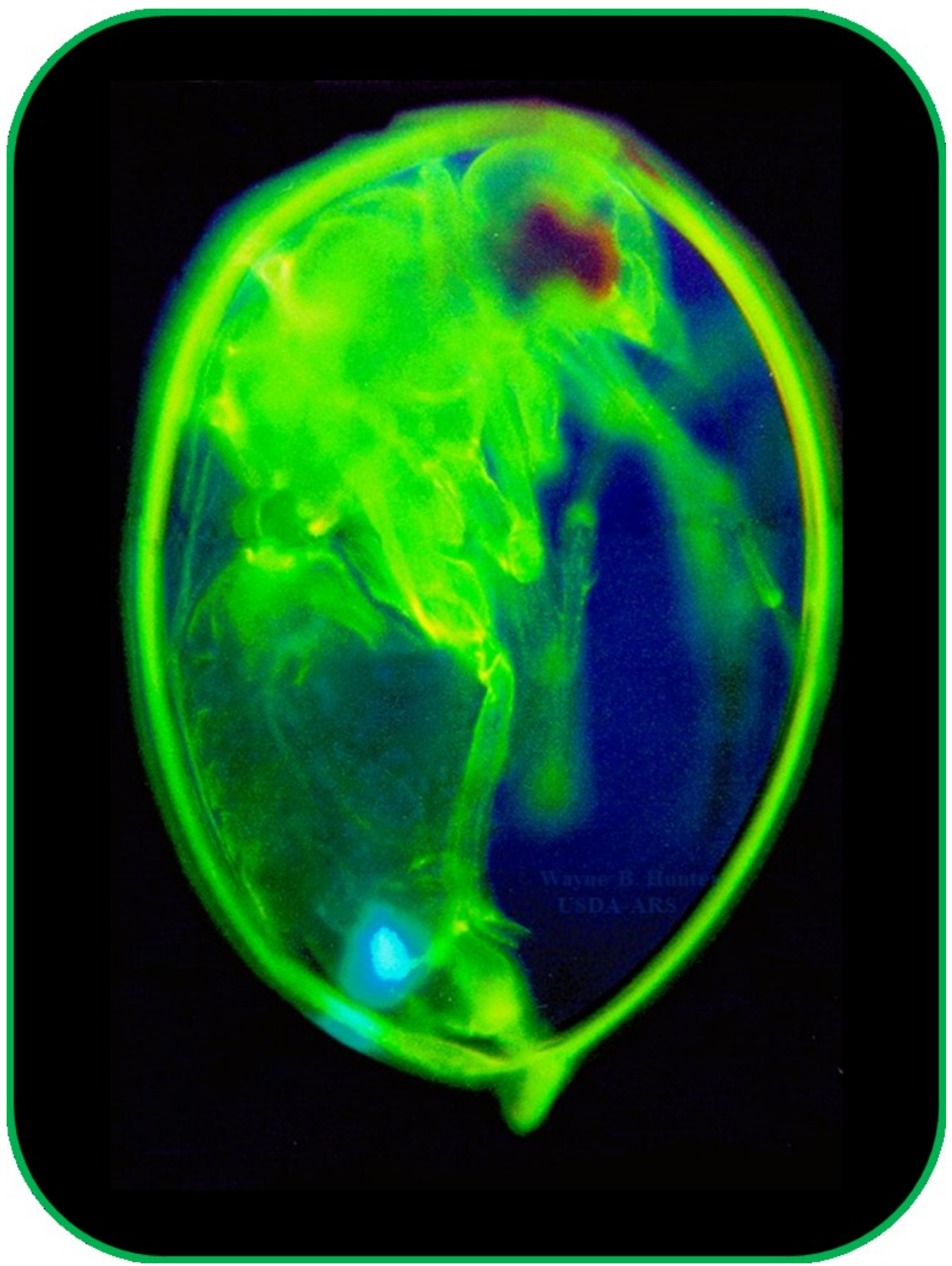

Fig. 1. Immunostained Whitefly, Bemisia argentifolii (aka. B. tabaci, B-Biotype)

49 (Hemiptera: Aleyroididae) Vector of Begomoviruses (Photo: Wayne Hunter, USDA-ARS ). 


\section{INTRODUCTION}

Today's political climate of uncertainty contains warnings of dangers from biological

54 agents that may cause harm to humans, animals, or food crops. These concerns include agents

55 that can be spread as airborne particulates and have spurred renewed interest in the development

56 and application of methods to collect, sample, and identify airborne organisms and chemicals.

57 Microorganisms such as bacteria, fungal spores, and viruses carried by air movements are

58 referred to as bioaerosols (Harper 1961; Killingley et al, 2013; Kumar et al, 2018) . While most

59 research on bioaerosol sampling has focused primarily on human and animal pathogens (Belser

60 et al, 2013; 2016; Gustin et al, 2013; Kormunth et al, 2018; Mitchell et al, 2003; Roux et al,

61 2013; Suresh and Ricke 2002; Yamamoto et al, 2010). This study applied this emerging

62 technology to the detection of insect-transmitted plant pathogens, specifically the whitefly-

63 transmitted Begomoviruses that threaten many of the subsistence crops worldwide (Czosnek et

64 al, 2017; Moffat 1999: Polston and Andersen 1997: Rosario, et al, 2014). Some of the

65 advantages being realized are the ability to capture and detect diseases as bioaerosols, thus

66 reducing the time and costs associated with monitoring disease presences or spread (Roux et al,

67 2013). Reducing costs and time in detection are critical components in the management of viral

68 pathogens in humans (Cowling et al, 2013; Kormunth et al, 2018; Paynter 2015), but also when

69 trying to manage and detect pathogens in urban or agricultural settings (Brodie et al, 2007).

70 Electrostatic sampling is a rapid method to screen for the occurrence of human, animal, or plant

71 pathogens which is not restricted by private property lines, crop type, or variety of samples

72 collected, as the air flow provides a broad 'sampling stream' (Holt et al, 1999; Parvaneh, et al,

73 2000; Mehta et al, 2000; Suresh and Ricke 2002). 
Recent advances in sampling, combined with breakthroughs in molecular techniques, and

75 bioinformatics, permits the rapid collection and identification of microbes, like virus and

76 bacteria, in a viable condition (Agranovski et al, 2005; Gerone et al, 1996). Thus, the microbe

77 may be cultured, as well as extracted using the DNA and/or RNA sequences to identify each

78 organism. (Hunter et al, 2001; Funk et al, 2001; Hunter and Polston 2001; Marutani-Hert et al,

79 2009; Rosario, et al, 2014; Sinisterra et al, 2005; Valles et al, 2004, 2008; 2018). However,

80 genetic analyses works independently of the ability to propagate a microbe in culture (Chen et

81 al, 2016; Hunter et al, 2003,2009; Tokarz et al, 2018; Valles et al, 2018). The combination of

82 these techniques thus have propelled the application of bioaerosol sampling into use as a new

83 and rapidly evolving field of pathogen detection. The use of Electrostatic Sampling Devices

84 (ESD) provides advantages that are beyond the normal detection methods of sample collecting.

85 The microbe can be collected on a grounded piece of metal, or directly into selective or general

86 culture media (when sampling for bacteria or fungi) (Gast et al, 1999; Holt et al, 1999; Mitchell

87 et al, 2002; Willeke and Macher, 1999; Richardson et al, 2003ab). Recognizing the future of

88 bioaerosol sampling this study evaluated if the small, newly designed electrostatic sampling

89 device, ESD, would be a suitable to collect enough virus as bioaerosol for detection and

90 monitoring of insect-transmitted plant pathogens. Air samplers are designed to monitor

91 buildings which use continuous air sampling, the needs of agricultural cropping systems are

92 focused on a device that is low in cost, easy to transport and sterilize, while being adaptable for a

93 variety of agricultural crops.

94 The Electrostatic Sampling Device (ESD) designed by Drs. B. Mitchell and R. Gast (Patent

95 7,046,011, May 2006) was specifically designed to collect airborne particulates such as bacteria,

96 viruses and fungal spores by using sharp-pointed electrodes that produce a focused electrostatic 
97 field with a high negative, direct-current voltage, generating a strong electrostatic field close to a

98 grounded collector (FIG. 2A). The grounded collector is typically an agar plate with selective

99 media on it for bacterial collections, or a dry metal plate, disc or rod to collect viruses. As

100 charged particles are drawn to the collector, air adjacent to the particles is also drawn in, causing

101 an airflow stream directed toward the collector (FIG. 2B). The number of microorganisms

102 collected by this method is equivalent to at least that of a $100 \mathrm{~L} / \mathrm{min}$ forced air impaction sampler

103 (Gast et al, 2004; Mitchell et al, 2003). The numbers of organisms collected by the ESD in a

104 given unit of time was very consistent in repeated trials collecting airborne bacteria, Salmonella

105 and Enterobacteriacea, from poultry houses, produced deposition patterns of similar uniformity

106 to those obtained by settling plates or impaction samplers (Gast et al, 2003, 2004; Mitchell et al,

107 2003; Richardson et al, 2003b). The ESD has an equivalent airflow rate of approximately 100

108 Liters/min, and the collected organisms are tightly held by electrostatic attraction. The airflow

109 patterns have been demonstrated artificially using smoke sticks adjacent to the sampler, and in

110 real life direct comparisons between impaction samplers and the ESD have shown equivalent

111 results (Gast et al, 2003, 2004; Richardson et al, 2003b) (Fig. 2B). The ESD has no blower, the

112 sampling area is not limited to a chamber, it requires a very low power source, thus enabling it to

113 operate for $16 \mathrm{hrs}$ on two small 9V batteries, The ESD is inexpensive to manufacture, rugged,

114 and easy to disinfect (Mitchell et al, 2003).

115 Begomoviruses are whitefly-transmitted, single-stranded, DNA plant infecting viruses

116 (Czosnek et al, 2001; Polston and Andersen 1997; Zerbini et al, 2017), and are known for reduce

117 major food crops world-wide, including tomato, beans, and cassava (Njorage, et al, 2017; Moffat

118 1999; Saeed and Samad 2017). Virions leave the insect body either via the salivary ducts,

119 passing down the insect's stylets during feeding thus being deposited into plant tissues (Ghanim 
120 et al, 2001; Rosell et al, 1999) or along with excreta as droplets into the air. Excretion of virus is

121 most likely the route of virus becoming aerosolized (Czosnek et al, 2001, 2002; Gast et al, 2003;

122 Hunter et al, 1998; Sinisterra et al, 2005). Whiteflies (Hemiptera: Aleyrodidae) aggregate in

123 large numbers on plants (McKenzie 2002; Saeed and Samad 2017) and as thousands of excreta

124 droplets fall from the plants during insect feeding the virus becomes aerosolized. Once the virus

125 or bacteria becomes airborne they may travel alone or become associated with dust or other

126 particulates in the air, and may then travel an unknown distance based upon wind flow and speed

127 (Kormunth et al, 2018; Xie, et al, 2007). Depending upon environmental conditions such as

128 temperature and moisture, the type of virus, or the time exposed to ultra-violet light, viruses may

129 become inactivated within minutes to hours, or may remain viable for weeks (Marutani-Hert et

130 al, 2009; Kanakala and Ghanim 2016). Stability traits of viruses make them detectible by

131 molecular methods, which analyze the presence of viral nucleic acids. To use these methods the

132 virus must first be collected. Most plant virus monitoring programs depend on taking plant

133 tissue samples, or insects, that then undergo nucleic acid extraction and analyses with ELISA or

134 PCR methods. Samples are usually selected based upon visual inspection by a person that will

135 scout the field for plant tissues showing disease symptoms, or hosting insects. The use of

136 bioaerosol sampling is based on the airflow moving the virus or bacteria through the collecting

137 zone (Agranovski et al, 2005; Brodie et al, 2007; Mehta et al, 2000; Parvaneh, et al, 2000;

138 Richardson et al, 2003; Yamamoto et al, 2010) (Fig. 3), thus being captured by the electrostatic

139 field produced by the ESD.

140 MATERIALS AND METHODS

141 Test Procedure for Sampling Poultry House Exhaust Air - The ESD was compared to settling

142 plates and a SAS-90 (Bioscience International, Rockville, MD)(Gast et al, 2003, 2004). 
143 Previously reported results from rigorous trials with the ESD in rooms with caged chicken egg

144 layers infected with Salmonella enteritidis, using selective MacConkey media (for

145 Enterobacteriacea - gram negative bacteria), air samples were taken only at intervals of 5.6 min

$146(500 \mathrm{~L})$ and $11.1 \mathrm{~min}(1000 \mathrm{~L})$ demonstrated positive collection and culturing of the bacterial

147 pathogen (Gast et al, 2003, 2004; Richarson et al, 2003).

148 Trials, Source and Maintenance of Insects and Plants - Colonies of whiteflies biotype-B

149 [Bemisia argentifolii (Gennadius)] were obtained from laboratory colonies maintained by the

150 U.S. Horticultural Research Laboratory, Ft. Pierce, FL. Whiteflies used in these experiments

151 were maintained on dwarf cherry tomato (Lycopersicon esculentum cv. Florida Lanai) since

1521996 by serial transfers (McKenzie 2002). Whitefly biotyping was based on RAPD PCR

153 analysis using primers developed by De Barro and Driver (1997). Viruliferous whitefly colonies

154 were housed in screened Plexiglass ${ }^{\circledR}$ cages located in a walk-in environmental growth chamber

155 (Environmental Growth Chambers, Chagrin Falls, $\mathrm{OH}$ ) at $25 \pm 1{ }^{\circ} \mathrm{C}$ under a 16:8 light/dark

156 photoperiod and an average light intensity of $700 \mu \mathrm{E}$ PAR at top of plant canopy.

157 ESD Sampling -The ESD is a multi-pin model, which runs on two nine volt batteries. The 158 collector plate was a electically grounded metal scoopula, $17.5 \mathrm{~cm}$ long, $1.4 \mathrm{~cm}$ wide, and set $1592.5 \mathrm{~cm}$ below pins, upon which the particulates would adhere through static charge (Mitchell et 160 al, 2003; Mitchell and Gast 2006). The ESD was set on the same table with the collector parallel

161 to the infested plant. The $\sim 250$ adult whiteflies were given settling times of 5-6 d pre-sampling.

162 The ESD was set up at two distances from the infested plant, at $30 \mathrm{~cm}$ and $60 \mathrm{~cm}$, samples were 163 collected at two time durations, 1 and 2 hrs (gels similar Fig. 2C).

164 Validation of virus from whiteflies and plants. The Tomato yellow leaf curl virus (TYLCV) 165 whitefly colony was established then serial transferred to dwarf cherry tomato cultivar. DNA 
was extracted from one, two, or three whiteflies using the AquaPure ${ }^{\mathrm{TM}}$ Genomic DNA isolation

167 kit (Bio-Rad, California). DNA extraction protocol in Edwards et. al. (1991). Validation of

168 viruses was accomplished by PCR amplification of plant or insect samples with virus specific

169 primers). Primers: TYLCV Pico-L 5'-CGCCCGTCTCGAAGGTTC-3', TYLCV Pico-R 5'-

170 GCCATA TACAATAACAAGGC-3' (Pico et al. 1998), ToMoV1: CP1 ToMoV (aka EH 289)

171 5'-GCC TTCTCAAACTTGCTCATTCAA T-3', CP2 ToMoV (aka EH 290) 5'-

172 GTtCGCAACAAA CAGAgTGTAT-3'. (Sinisterra et al, 2005; Pico et al, 1998). The PCR

173 reaction was accomplished as follows: $45 \mu \mathrm{L}$ Platinum ${ }^{\circledR}$ PCR Supermix (Invitrogen), $2 \mu \mathrm{L}$ Depc

$174 \mathrm{H}_{2} \mathrm{O}, 2 \mu \mathrm{L}$ Primers, $1 \mu \mathrm{L}$ DNA in a final volume of $50 \mu \mathrm{L}$. Cycle reaction was $94^{\circ} \mathrm{C}$ for 2 min,

175 then 35 cycles of $\left(94^{\circ} \mathrm{C}\right.$ for $15 \mathrm{sec}, 46.5^{\circ} \mathrm{C}$ for $1: 35 \mathrm{~min}, 72^{\circ} \mathrm{C}$ for $\left.1: 00 \mathrm{~min}\right)$.

176 Begomovirus Immuno-labeling - Live adult whiteflies were immobilized by placing them in a

177 standard $-20^{\circ} \mathrm{C}$ freezer, for $\sim 3-5 \mathrm{~min}$, then placing the live, immobilized insect onto a drop of

178 clear fingernail polish. Whiteflies were covered with $10 \mathrm{mM}$ phosphate buffer saline (PBS), $\mathrm{pH}$

179 7.4, (Sigma Co., P-3813, St. Louis, MO) and dissected. More details on dissection, labeling and

180 processing described in (Hunter et al, 1998; Sinisterra et al, 2005; Cancino et al, 1995) (Fig. 1).

181 Experimental design - The ESD was set at three distances (next to plant, $30 \mathrm{~cm}$, and $60 \mathrm{~cm}$ ) from

182 whitefly infested, caged tomato plants, which had been validated as being infected with TYLCV

183 and which were contained within a growth room. The ESD was let run for two time periods, $1 \mathrm{hr}$

184 and $2 \mathrm{hrs}$, to evaluate efficiency of virus capture. All experiments were replicated three times.

185 RESULTS AND DISCUSSION

186 Sixteen of the 18 independent ESD samplings $(88.9 \%)$ resulted in positive detection of

187 TYLCV as a pathogen bio-aerosol being excreted by whiteflies. Twelve independent one hour

188 sample durations resulted in 11 TYLCV positive PCR detections by the ESD collecting at both 
30 and $60 \mathrm{~cm}$ from test plants. Six independent two hour sample durations resulted in five

190 positive TYLCV detections at both distances. In all trials virus capture as evident by PCR band

191 strength appeared to be greatest when closer to infested plants (Fig. 2C, other gels not shown).

192 Our data demonstrates that Begomovirus becomes aerosolized from whitefly infested tomato,

193 and was successfully captured by the ESD (Fig. 2C). Furthermore, the ESD is suitable to capture

194 other aerosolized insect-transmitted viruses (Agranovski et al, 2005; Mainelis et al, 1999;

195 Mitchell and King 1994; Mitchell and Waltman 2003) or bacteria, (Gerone et al, 1996; Holt et al,

196 1999; Mitchell et al, 2002), aerosolized during feeding (Suresh and Ricke 2002) (Fig. 3).

197 However, detection does not demonstrate virus viability nor spread as a contagion. Depending

198 upon environmental conditions such as temperature and moisture, the type of virus or bacteria,

199 and the time exposed to ultra-violet light, microorganisms may become inactivated within

200 minutes to hours, or remain viable for days $(31,32)$. The results show and we propose that

201 electrostatic detection methods are a rapid aid in the collection of bioaerosol pathogens for

202 detection and identification in agricultural systems (Brodie et al, 2007; Gustin et al, 2013;

203 Kormuth, et al, 2018; Suresh and Ricke 2002; Richardson et al, 2003). The ESD will find many

204 applications in the monitoring of different systems whether these are crop plants, or chicken

205 houses; farm yards, or back yards, the ESD provides a low cost solution to one of the growing

206 concerns of today's world.

207 Acknowledgements:

208 We thank Laura Hunnicutt, Biological Science Technician, USDA, ARS, Fort Pierce, FL, for

209 technical support and analyses.

210 
bioRxiv preprint doi: https://doi org/10 1101/451559. this version posted October 24.2018 The copvriaht holder for this preprint (which was not certified by peer review) is the author/funder. This article is a US Government work. It is not subject to copyright under 17 USC 105 and is also made available for use under a CCO license.

213 Mention of proprietary or brand names are necessary to report factually on available data;

214 however, the USDA neither guarantees nor warrants the standard of the product, and the use of

215 the name by USDA implies no approval to the exclusion of others that also may be suitable. This

216 article is in the public domain and not copyrightable. Publication may be freely reprinted with

217 customary crediting of source.

218 


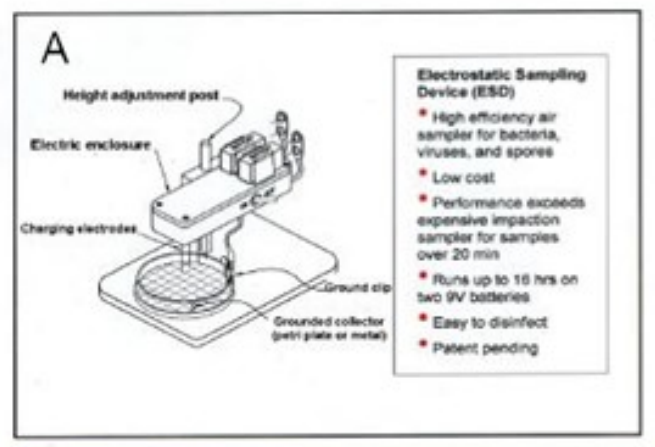

C
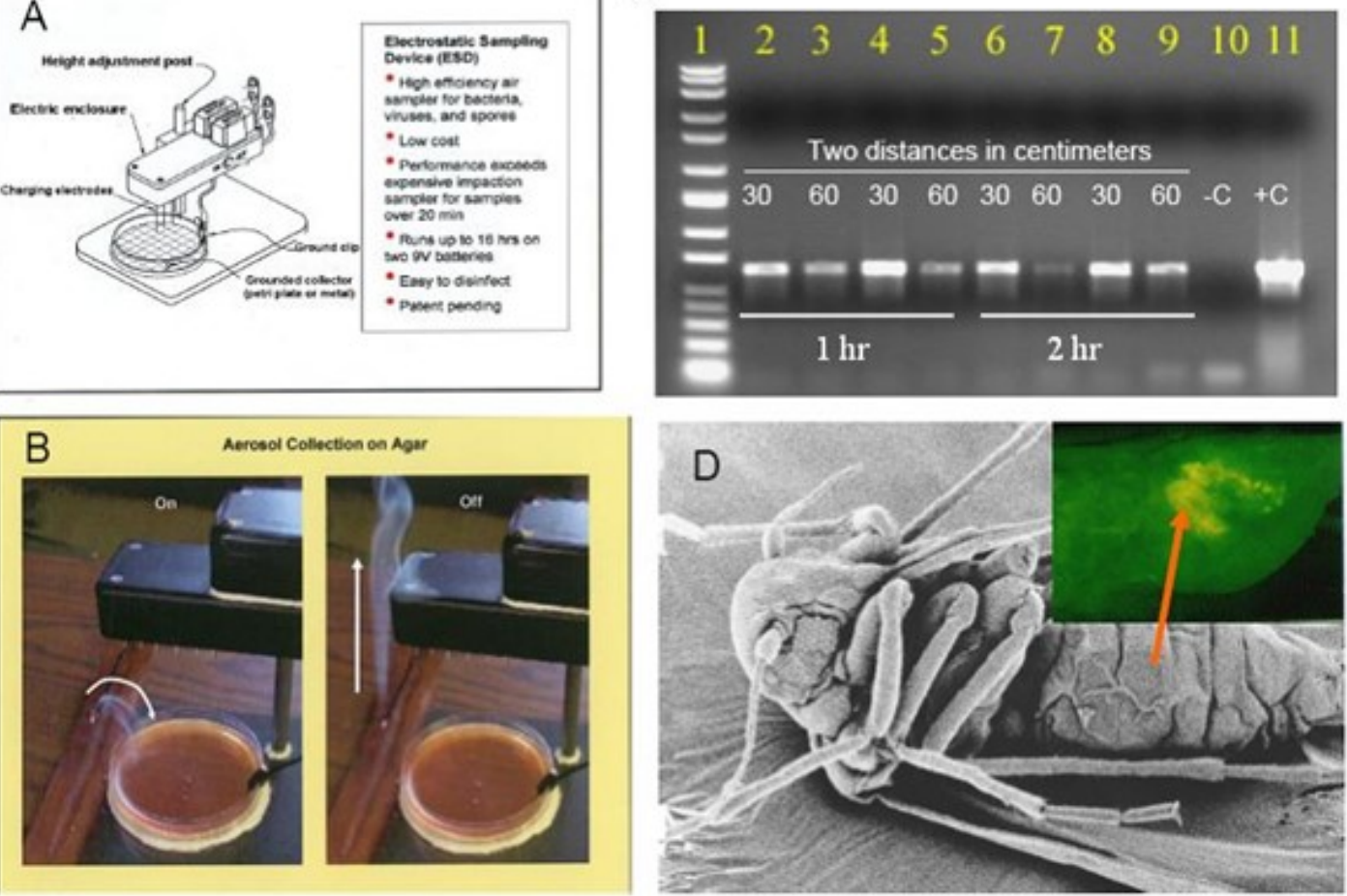

Figure 2. Capture, collection and detection of the Begomovirus, Tomato yellow leaf-curl virus,

221 TYLCV, in air as a bioaerosol using an electrostatic sampling device, ESD. (A) Diagram of

222 electrostatic device, ESD. (B) Smoke used to show electrostatic pull of bio-aerosols a grounded

223 agar plate. The collecting surface may also be a metallic plate, rod, or agar plate (Mitchell et al,

224 2002; Mitchell and Gast 2003). (C) Gel showing results of samples collected from the grounded

225 metal scoopula, sterile cotton swab, when ESD was placed at two distances, 30 and $60 \mathrm{~cm}$, from

226 tomato plant infested with B. tabaci. Durations were one and two hours respectively.

227 Begomovirus source was an uncaged whitefly colony feeding on a TYLCV infected tomato

228 plant. (D) Scanning electron micrograph image of a whitefly adult, with inset showing FITC

229 immunolabeled TYLCV within the whitefly digestive system after feeding on infected tomato

230 (arrow)(method in Hunter et al , 1998). TYLCV enters the hemolymph and replicates within the

231 whitefly (Sinisterra et al, 2005). Virus passes out with saliva (Rosell et al, 1999) and excreta

232 during feeding becoming aerosolized. 
bioRxiv preprint doi: https://doi.org/10.1101/451559; this version posted October 24,2018 . The copyright holder for this preprint (which was not certified by peer review) is the author/funder. This article is a US Government work. It is not subject to copyright under 17 USC 105 and is also made available for use under a CCO license.
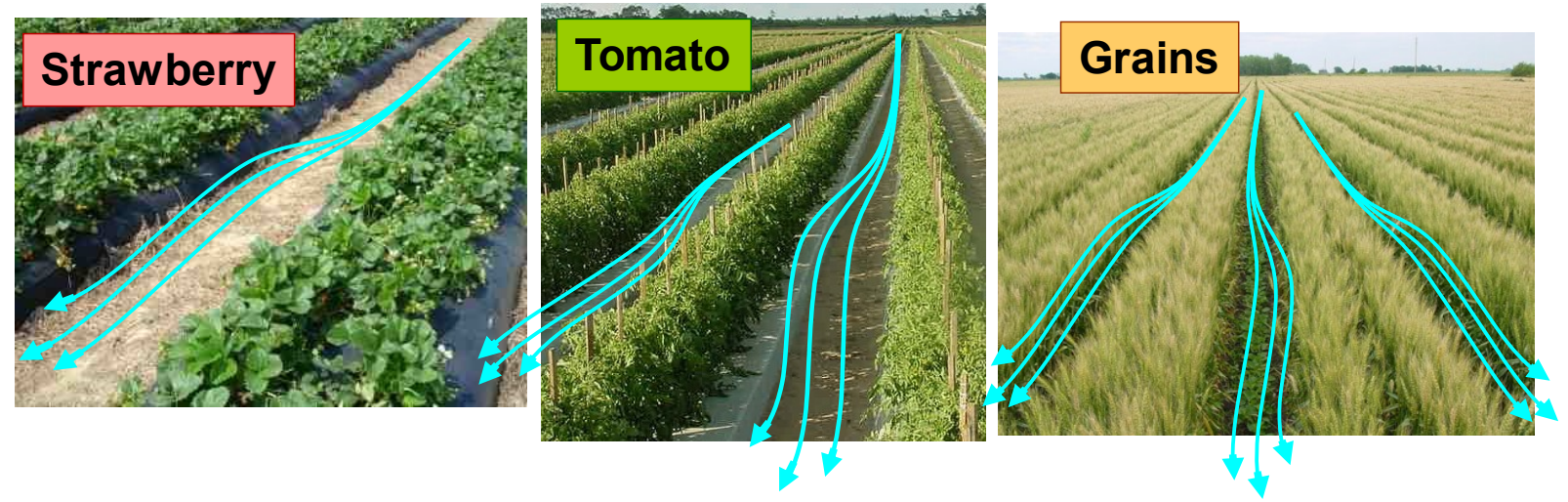

Figure 3. Diagrammatic representation of natural air flow through different rows of crops. As

236 air travels down the rows it carries airborne pathogens, fungal spores and dust. 


\section{REFERENCES}

Agranovski, I., Safatov, A., Pyankov, O., Sergeev, A., Grinshpun, S. 2005. Long-term sampling of viable airborne viruses. Aerosol Science and Technology 39:912-918. Belser, J.A., Davis, C.T., Balish, A., Edwards, L.E., Zeng, H., Maines, T.R., Gustin, K.M., Martinez, I.L., Fasce, R., Cox, N.J., Katz, J.M., Tumpey, T.M. 2013. Pathogenesis, transmissibility, and ocular tropism of a highly pathogenic avian influenza A (H7N3) virus associated with human conjunctivitis. J Virol 87:5746-5754. doi:10.1128/JVI.00154-13. Belser, J.A., Creager, H.M., Sun, X., Gustin, K.M., Jones, T., Shieh, W-J., Maines, T.R., Tumpey, T.M. 2016. Mammalian Pathogenesis and Transmission of H7N9 Influenza Viruses from Three Waves, 2013-2015. Journal of Virology 90(9):4647-4657. Doi:10.1128/JVI.0013416. Andersen. 2007. Urban aerosols harbor diverse and dynamic bacterial populations. PNAS 104:299-304. distinguishing bean golden mosaic virus isolates. Phytopathology 85:484-490. Bemisia tabaci, a globally important crop pest and virus vector. BMC Biology (2016) 14:110. Doi:10.1186/s12915-016-0321-y.

Cowling, B.J., Ip, D.K.M., Fang, V.J., et al. 2013. Aerosol transmission is an important mode of influenza A virus spread. Nature Commun. 4:1935. Doi:10.1038/ncomms2922. Whiteflies: vectors, and victims, of geminiviruses. Adv. Virus Res. 57:291-321. whitefly vector Bemisia tabaci - insights from studies with Tomato yellow leaf curl virus. Ann. Appl. Biol.140:215-231. journey of Begomoviruses in their whitefly vector. Viruses 9:273. Doi:10.3390/v9100273 De Barro, P.J. and F. Driver. 1997. Use of RAPD PCR to distinguish the B biotype from other biotypes of Bemisia tabaci (Gennadius) (Hemiptera: Aleyrodidae). Aust. J. Entomol. 36:149-152.

275

Edwards, K., Johnstone, C., Thompson, C. 1991. A simple and rapid methods for the preparation of plant genomic DNA for PCR analysis. Nucl. Acids Res. 19:1349. 
Gast, R.K., Mitchell, B.W., Holt, P.S. 1999. Application of negative air ionization for reducing experimental airborne transmission of Salmonella enteritidis to chicks. Poultry Sci. 78:57-61. the environment of experimentally infected laying hens by an electrostatic sampling device. Avian Dis. 48:148-154. Salmonella enteritidis in the environment of experimentally infected laying hens with an electrostatic sampling device. Poultry Sci. 83:1106-1111. Assessment of experimental and natural viral aerosols. Bacterial. Rev. 30:576-588. translocation in the circulative transmission pathway of its vector, the whitefly Bemisia tabaci. Phytopathology 91:188-196. infectious virus in respirable aerosols exhaled by ferrets infected with influenza viruses exhibiting diverse transmissibility phenotypes. Journal of Virology 87(14):7864-7873. Doi:10.1128/JVI.00719-13.

Harper, G.J. 1961. Airborne micro-organisms: survival tests with four viruses. Journal of Hygiene 59(4):479-486. [PMC free article] [PubMed]

Holt, P.S., B.W. Mitchell, K.H. Seo, and R.K. Gast. 1999. Use of negative air ionization for reducing airborne levels of Salmonella enterica serovar Enteritidis in a room containing infected caged layers. J. Appl. Poultry Res. 8:440-446. McKenzie, C.L., Sinisterra, X.H. 2003. Aphid biology: Expressed genes from alate Toxoptera citricida (Kirkaldy), brown citrus aphid (Hemiptera: Aphididae). Journal of Insect Science. http://www.insectscience.org/3.23. the whitefly Bemisia tabaci (Homoptera: Aleyrodidae). Plant Dis. 82:1147-1151. Discovering new insect viruses: Whitefly iridovirus (Homoptera: Aleyrodidae: Bemisia tabaci). Journal of Invertebrate Pathology 78:220-225. Doi:10.1006/jipa.2001.5060.

Hunter, W.B. and Polston, J.E. 2001. Development of a continuous whitefly cell line [Homoptera: Aleyrodidae: Bemisia tabaci (Gennadius)] for the study of Begomovirus. J. Invertebrate Pathology. 77:33-36. Doi:10.1006/jipa.2000.4993. Psyllid biology: expressed genes in adult Asian citrus psyllids, Diaphorina citri Kuwayama.

316 Roux, J.M., Kaspari, O., Heinrich, R., Hanschmann, N., Grunow, R. 2013. Investigation of 317 a New Electrostatic Sampler for Concentrating Biological and Non-Biological Aerosol 
Particles, Aerosol Science and Technology 47(5):463-471. Doi:10.1080/02786826.2013.763896 L.C. 2018. Influenza virus infectivity Is retained in aerosols and droplets independent of relative humidity. The Journal of Infectious

Diseases, 218(5):739-747.

322 Doi.org/10.1093/infdis/jiy221.

323 Kanakala, S., and Ghanim, M. 2016. RNA Interference in Insect Vectors for Plant Viruses.

324 Viruses 8:329. Doi:10.3390/v8120329.

325 Kumar, B., Manuja, A., Gulati, B., Virmani, N., Tripathi, B.N. 2018. Zoonotic Viral 326 Diseases of Equines and Their Impact on Human and Animal Health. The Open Virology 327 Journal, 12, 80-98. http://doi.org/10.2174/1874357901812010080.

328 Mainelis, G., Grinshpun, S.A., Willeke, K., Reponen, T., Ulevicius, V., Hintz, P.J. 1999. 329 Collection of airborne microorganisms by electrostatic precipitation. Aerosol Sci. Tech. 30:127330144.

331 Marutani-Hert, M., Hunter, WB, Katsar, CS, Sinisterra, X.H., Hall, D.G., Powell, CA. 332 2009. Reovirus-like sequences isolated from adult Asian citrus psyllid, (Hemiptera: Psyllidae: 333 Diaphorina citri). Florida Entomologist 92:314-320.

334 McKenzie, C.L. 2002. Effect of Tomato mottle virus (ToMoV) on Bemisia tabaci biotype B 335 (Homoptera: Aleyrodidae) oviposition and adult survivorship on healthy tomato. Fla Entomol. $336 \quad 85: 367-368$.

337 Mehta, S.K., Bell-Robinson, D.M., Groves, T.O.L., Stetzenbach, D., Pierson, D.L..2000. 338 Evaluation of portable air samplers for monitoring airborne culturable bacteria. AIHAJ. 61:850339854.

340 Mitchell, B.W., Buhr, R.J., Berrang, M.E., Bailey, J.S., Cox, N.A. 2002. Reducing airborne 341 pathogens, dust and Salmonella transmission in experimental hatching cabinets using an 342 electrostatic space charge system. Poultry Sci. 81:49-55.

343 Mitchell, B.W., and R. K. Gast. 2006. Patent application U.S. Patent Office. Serial No.: 344 10/670,5757,046,011, May 2006.

345 Mitchell, B.W. and King, D.J. 1994. Effect of negative air ionization on airborne transmission 346 of Newcastle disease virus. Avian Dis. 38:725-732.

347 Mitchell, B.W., Richardson, J., Wilson, J., Hofacre, C.L. 2003. Application of an 348 electrostatic space charge system for dust, ammonia, and pathogen reduction in a broiler breeder 349 house. Applied Engr. In Agri. 20:87-93.

350 Mitchell, B.W., and Waltman, W.D. 2003. Reducing airborne pathogens and dust in 351 commercial hatching cabinets using an electrostatic space charge system. Avian Dis. 47:247352253.

353 Moffat, A.S. 1999. Geminiviruses emerge as serious crop threat. Science 286(5446), 1835.

354 Njoroge, M.K., Mutisya, D.L., Miano, D.W., Kilalo, D.C. 2017. Whitefly species efficiency 355 in transmitting cassava mosaic and brown streak virus diseases. Cogent Biology 3:1311499.

356 Doi.org/10.1080/23312025.2017.1311499. 

2000. A new method for collecting airborne allergens. Allergy. 55:1148-1154. Paynter, S. 2015. Humidity and respiratory virus transmission in tropical and temperate settings. Epidemiology \& Infection 143(6):1110-1118. Doi:10.1017/S0950268814002702. Pico, B., Diez, M.J., Nuez, F. 1998. Evaluation of whitefly-mediated inoculation techniques to screen Lycopersicon esculentum and wild relatives for resistance to Tomato yellow leaf curl virus. Euphytica 101:259-271. Polston, J.E. and P.K. Andersen. 1997. The emergence of whitefly-transmitted geminiviruses in tomato in the Western Hemisphere. Plant Dis. 81:1358-1369. Metagenome of Whiteflies Leads to the Discovery and Characterization of a WhiteflyTransmitted Carlavirus in North America. PLoS ONE 9(1): e86748. https://doi.org/10.1371/journal.pone.0086748 transmission pathway by polymerase chain reaction in whitefly extracts, saliva, hemolymph, and honeydew. Phytopathology 89:239-246. space charge on reduction of airborne transmission of Salmonella and other bacteria during the lay cycle and to the progeny of broiler breeders. Avian Dis. 47:1352- 1361. Richardson, L.J., Mitchell, B.W., Wilson, J.L., Hofacre, C.L. 2003b. Effect of an electrostatic space charge system on airborne dust and subsequent potential transmission of microorganisms to broiler breeder pullets by airborne dust. Avian Dis. 47:128-133. medicinal and aromatic crops and their management strategies. Virus Disease 28(1):1-17. Doi.org/10.1007/s13337-016-0358-0.

Sinisterra, XH., McKenzie, C.L., Hunter, W.B., Powell, C.A., Shatters, RG. 2005. Differential transcriptional activity of plant-pathogenic begomoviruses in their whitefly vector (Bemisia tabaci, Gennadius: Hemiptera Aleyrodidae). J. Gen. Virol. 86:1525-32. Doi:10.1099/vir.0.80665-0.

386 Suresh, D.P., and Ricke, S.C. 2002. Bioaerosols from municipal and animal wastes: background and contemporary issues. Can. J. Microbiol. 48:681-696. Identification of novel viruses in Amblyomma americanum, Dermacentor variabilis, and Ixodes scapularis ticks. mSphere 3:e00614-17. Doi.org/10.1128/mSphere.00614-17.

391 Valles, S.M., Porter, S.D., Calcaterra, L.A. 2018. Prospecting for viral natural enemies of the

392 fire ant Solenopsis invicta in Argentina. PLoS ONE 13(2): e0192377.

393 https://doi.org/10.1371/journal.pone.0192377

394 Valles, S.M., Strong, C.A., Dang, P.M., Hunter, W.B., Pereira, R.M., Oi, D.H., et al. 2004.

395 A picorna-like virus from the red imported fire ant, Solenopsis invicta: initial discovery, 
396 genome sequence, and characterization. Virology 328(1):151-157.

397 Doi.org/10.1016/j.virol.2004.07.016 S0042-6822(04)00491-X.

398 Valles, S.M., Strong, C.A., Hunter, W.B., Dang, P.M., et al. 2008. Expressed sequence tags

399 from the red imported fire ant, Solenopsis invicta: annotation and utilization for discovery of

400 viruses. Journal of Invertebrate Pathology. 99(1):74-81. Doi.org/10.1016/j.jip.2008.01.004

401 PMID: 18329665.

402 Valles, S.M., Porter, S.D., Calcaterra, L.A. 2018. Prospecting for viral natural enemies of the

403 fire ant Solenopsis invicta in Argentina. PLoS ONE 13(2): e0192377.

404 https://doi.org/10.1371/journal.pone.0192377

405 Willeke, K., and J.M. Macher. 1999. Air Sampling. Chapter 11 in Bioaerosols Assessment 406 and Control. ACGIH. Cincinnati, OH. 1-25.

407 Xie, X., Li, Y., Chwang, A.T., Ho, P.L., Seto, W.H. 2007. How far droplets can move in 408 indoor environments-revisiting the Wells evaporation-falling curve. Indoor Air 17:211-225. 409 Doi:10.1111/j.1600-0668.2007.00469.x.

410 Yamamoto, N., Shendell, D.G., Winer, A.M., Zhang, J. 2010. Residential air exchange rates 411 in three major US metropolitan areas: results from the relationship among indoor, outdoor, and 412 personal air study 1999-2001. Indoor Air 20:85-90. Doi:10.1111/j.1600-0668.2009.00622.x.

413 Zerbini, F.M., Briddon, R.W., Idris, A., Martin, D.P., Moriones, E., Navas-Castillo, J., 414 Rivera-Bustamante, R., Roumagnac, P., Varsani, A. 2017. ICTV Report Consortium. ICTV 415 Virus Taxonomy Profile: Geminiviridae. J Gen Virol. 98(2):131-133. 416 Doi:10.1099/jgv.0.000738. 